\title{
Trace metal concentrations in the North-western Mediterranean atmospheric aerosol between 1986 and 2008: Seasonal patterns and decadal trends
}

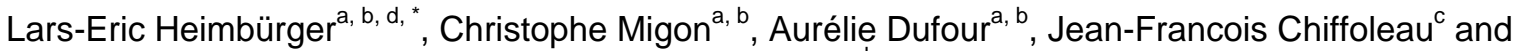 \\ Daniel Cossa $^{\mathrm{d}}$
}

\author{
a UMPC Univ. Paris 06, UMR 7093, LOV, Observatoire océanographique, F-06234, Villefranche/Mer, France \\ ${ }^{b}$ CNRS, UMR 7093, LOV, Observatoire océanographique, F-06234, Villefranche/Mer, France \\ ${ }^{c}$ IFREMER, Centre Nantes, BP 21109, F-44311, Nantes, France \\ d IFREMER, Centre de Méditerranée, BP 330, F-83507, La Seyne-sur-Mer, France \\ *: Corresponding author : Lars-Eric Heimbürger, Tel.: +33 493763986, email address : lars.heimbuerger@obs- \\ $\underline{\text { vlfr.fr }}$
}

\begin{abstract}
:
Climatic and anthropogenic changes are able to engender modifications in the aerosol composition at different geographical and temporal scales. The present study addresses this question for the trace metal concentrations ( $\mathrm{TM}=\mathrm{Al}, \mathrm{Fe}, \mathrm{Mn}, \mathrm{Co}, \mathrm{Ni}, \mathrm{Cu}, \mathrm{Pb}, \mathrm{Cd}$ and $\mathrm{Zn}$ ) of aerosol from the North-western Mediterranean coast of France (Cap Ferrat, nearby Nice) between 1986 and 2008. From seasonal variations (2006-08) and decadal trends (1986-2008) of TM concentrations, three groups of elements can be distinguished. They consist of different aerosol sources: crustal-derived elements ( $\mathrm{Al}, \mathrm{Fe}, \mathrm{Mn}$ and $\mathrm{Co}$ ), trace metals of anthropogenic origin ( $\mathrm{Pb}, \mathrm{Cd}$ and $\mathrm{Zn}$ ) and a third, intermediate, group of trace metals that presented both anthropogenic and natural/crustal influences ( $\mathrm{Ni}$ and $\mathrm{Cu}$ ). Reproducible seasonal patterns were observed for crustal and intermediate elements with highest concentrations between May and November, while anthropogenic trace metals did not show a pronounced seasonal cycle. Nevertheless, highest concentrations of anthropogenic trace metals occurred mostly in autumn/winter. Aerosol concentrations of anthropogenic TMs decreased remarkably over the last two decades, while crustal trace metals did not show any evolution. Nickel and copper aerosol concentrations remained constant, as well. Lead concentrations decreased from $1986\left(29.34 \mathrm{ng} \mathrm{m}^{-3}\right)$ to $2008\left(3.33 \mathrm{ng} \mathrm{m}^{-3}\right)$, overall by $90 \%$. Cadmium and zinc aerosol concentrations decreased by 66 and $54 \%$, respectively, between 1998 and 2006-08, from 0.27 to $0.09 \mathrm{ng} \mathrm{m}^{-3}$ and from 23.9 to $10.9 \mathrm{ng} \mathrm{m}^{-3}$, respectively. These findings demonstrate the response of the atmospheric environment to the implementation of antipollution policies. Possible changes of trace metal emissions sources and local influences are discussed.
\end{abstract}

Keywords: Trace metals; Aerosols; Anthropic impact; Mediterranean; Anti-pollution policy 


\section{Introduction}

Atmospheric transport is an efficient (and often the main) transport route by which both natural and anthropogenic compounds are carried from land-based emission sources to coastal and offshore marine waters (Jickells, 1995; Guerzoni et al., 1999). This is particularly true for the Mediterranean Sea, due to its relatively reduced dimensions $\left(2.510^{6} \mathrm{~km}^{2}\right.$, i.e. only $1 \%$ of the world oceanic surface), and because its open waters are never further than $300 \mathrm{~km}$ off the coasts. In addition, this semienclosed basin is subjected to ever growing anthropogenic pressure and natural pulsed Saharan dust events (Béthoux et al., 2002). Owing to these peculiarities, the interactions between land-based emissions sources and offshore waters are particularly strong, and they significantly affect the biogeochemistry of the Mediterranean Sea. As a result, the Mediterranean Sea is particularly sensitive and reactive to climatic and environmental changes, and can be used as an ocean model for climatic and environmental studies (Béthoux et al., 1999). Specifically, the Western basin may be regarded as having specific air mass back trajectories with little variation in the frequency of airflow patterns (World Meteorological Organization, 1985). Meteorological situations are contrasted, with a succession of dry (winter and summer) and wet (spring and autumn) seasons, which significantly determine the seasonal variability and the bioavailability of atmospheric deposition, and, thus, its further involvement in marine biogeochemical cycles (Nicolas et al., 1995).

The study of temporal trends of natural and anthropogenic compounds, especially trace metals (TM), in the Mediterranean atmosphere is therefore crucial to understand the causal relationships between changes in land-based emission sources and perturbations or evolutions in the biogeochemistry of oceanic areas. On the one hand, the further on-going industrialisation of Europe, in particular that of developing countries of the Eastern part, and of Southern Mediterranean countries, is likely to yield increasing atmospheric anthropogenic pressure on the Mediterranean Sea. On the second hand, the implementation of stricter environmental policies has already shown that the Mediterranean environment is very sensitive to changes in emissions of anthropogenic TMs. For example, the implementation of the antipollution policy on automotive lead in the second half of the 1980s has resulted in the rapid removal of lead in the North-western Mediterranean atmosphere (Migon et al., 1993a, 2008). On the basis of time-series data of atmospheric aerosol acquired at a Ligurian coastal sampling station over a period of more than twenty years, the present work attempts to study the seasonal behaviour and decadal trends of a series of TMs representative of the North-western Mediterranean Sea.

\section{Methods}

\subsection{Study site and sampling protocol}

Atmospheric aerosols were collected at the naval signal station of Cap Ferrat, situated on the southeastern coast of France $\left(43^{\circ} 41^{\prime} \mathrm{N}, 7^{\circ} 19^{\prime} 30^{\prime \prime} \mathrm{E}\right.$, altitude $130 \mathrm{~m}$; Fig. 1) between 1986 and 2009. The sampling site, situated on top of the peninsula of Cap Ferrat, is sheltered from local sea-spray and direct continental sources, although it exhibits a marked marine influence (Sandroni and Migon, 1997). The average rainfall is approximately $10 \%$ lower than that observed at the neighbouring weather station at the airport of Nice, situated on the shoreline (C.S.M., 1988). The Cap Ferrat site is overall affected by a homogeneous European urban-dominated background material, upon which episodic Saharan dust inputs are superimposed (Chester et al., 1997). More detailed discussion on the site (meteorological characteristics, surrounding anthropogenic influences, occurrence of Saharan events, etc.) can be found elsewhere (Migon and Caccia, 1990; Chester et al., 1997; Sandroni and Migon, 1997).

Long-term continuous sampling of atmospheric material is very difficult and even impossible at sea on research vessels. At present day, data are acquired from coastal or island sampling sites therefore (e.g., Chester et al., 1999; Güllü et al., 2000; Zhang et al., 2007). Background aerosols in the Ligurian Sea exhibit a relatively low variability, typically within a factor of 1.4 (e.g., Ni) to 3.2 (e.g., Al) from a 
coastal sampling site to another (Sandroni and Migon, 1997). Atmospheric fluxes of TMs measured at coastal sites may therefore be extrapolated to the sub-basin scale, as shown by comparison with ship-board aerosol sample collection (Jickells, 1995).

Aerosol samples were collected by pumping surrounding air through a Sartorius membrane (SM 11106, cellulose acetate, porosity $0.45 \mu \mathrm{m}$, diameter $47 \mathrm{~mm}$ ), placed on a filter holder connected to a low-volume pump (KNF IP 44) and a flow meter. This sampling apparatus was raised to the top of a 6 $\mathrm{m}$-high mast to avoid contamination with local soil dust. The average pumped volume was $175 \mathrm{~m}^{3}$, with a flow rate of $\sim 25 \pm 1 \mathrm{~m}^{3} \mathrm{~d}^{-1}$ over the duration of one week.

Atmospheric aerosol was monitored in 1986-87, 1992-93, 1994, 1995, 1996, 1997-98 and 2002-08. Data-sets for 1995, 1997 and 2006-08 are complete. The years 2004 and 2005 have also been sampled continuously for lead. Samples have been collected intermittently in 1986, 1987, 1994, 1996, 1998, 2003 and 2004, although Co, Ni, Cu, Zn, and Cd were not analysed in 2003 and 2004 samples.

\subsection{Sample mineralisation and analysis}

All reagents were provided by Merck (Darmstadt, Germany), quality Suprapur. All analyses were carried out under laminar airflow benches in a class 100 clean room. Samples were dissolved by acid treatment by sets of twelve samples, including two blank filters and two certified reference materials (CRM). Each filter was folded into 4 and introduced into an acid cleaned Teflon bottle $(7 \mathrm{~mL})$ in which $1 \mathrm{~mL} \mathrm{HNO}_{3}(65 \%)$ was added. The bottle was closed and put into a larger Teflon bottle $(60 \mathrm{~mL})$ and left at room temperature until complete dissolution of the membrane. Then, the apparatus was kept tightly closed for $12 \mathrm{~h}$ in an oven at $150^{\circ} \mathrm{C}$. Bottles were then cooled in a laminar airflow hood and left open until the red smoke had evolved (which indicates that all $\mathrm{HNO}_{3}$ has evaporated). The remainder was dissolved again with $500 \mu \mathrm{L} \mathrm{HNO}_{3}(14 \mathrm{M})$ and $300 \mu \mathrm{L} \mathrm{HF}(23 \mathrm{M})$ and left for $24 \mathrm{~h}$ (without evaporation) prior to being stored again in a drying oven for $12 \mathrm{~h}$. A white residue was obtained and dissolved in $1 \mathrm{~mL} \mathrm{HNO}_{3}(1 \mathrm{M})$, ultrasonically agitated for two hours and made up to $9 \mathrm{~mL}$ with Milli-Q water. The solution was finally stored in an acid cleaned polypropylene bottle $(10 \mathrm{~mL})$ until analysis. All reagents were Suprapur ${ }^{\circledR}$ grade, provided by Merck.

Due to the relatively long duration of the monitoring (1986-2008), analyses were carried out by four different detection techniques: graphite furnace atomic absorption spectrophotometry (GFAAS), differential pulse anodic stripping voltammetry (DPASV), inductively coupled plasma atomic emission spectroscopy (ICP-AES) and inductively coupled plasma mass spectrometer (ICP-MS). Table 1 gives an overview of the various techniques applied, and gives references for their analytical characteristics and performances.

\subsection{Quality assurance and quality control}

The analytical procedures (mineralisation + analysis) were regularly checked using CRMs (MESS-2 or MESS-3 from the National Research Council, Ottawa, Canada, and NIST-2783 Air particulate on filter media from the National Institute of Standards \& Technology). The results were always within the quoted confidence intervals, given for the CRMs. In addition, taking into account the variety of analytical techniques used over the years, we compared those techniques for the case of $\mathrm{Pb}, \mathrm{Cd}$ and $\mathrm{Zn}$ (TMs for which a temporal decrease was actually observed). Aerosol samples from the 2006-08 series were selected randomly and analysed by GFAAS $(\mathrm{Pb} ; \mathrm{n}=90)$ and DPASV $(\mathrm{Cd}$ and $\mathrm{Zn} ; \mathrm{n}=12)$ using the same protocol and apparatus as in earlier series, and compared with the more recent ICPMS results. The variations observed between two values of the same sample never exceeded $10 \%$ ( $\mathrm{Pb} 7 \%, \mathrm{Cd} 9 \%$ and $\mathrm{Zn} \mathrm{10 \% ).} \mathrm{Therefore,} \mathrm{TM} \mathrm{concentration} \mathrm{variations} \mathrm{higher} \mathrm{than} \mathrm{10 \%} \mathrm{must} \mathrm{be}$ interpreted as temporal environmental variations independent of any possible analytical bias due to change in the detection procedures. 


\section{Results}

Raw data is accessible online: www.obs-vlfr.fr/ heimbuerger/Files/AEROSOL online.pdf. Table 3 gives the summary statistics (geometric mean, arithmetic mean, standard deviation, extreme values, number of samples) of aerosol TM concentrations from 1986 to 2008. Geometric means are given, because the distributions of elemental concentrations in the atmospheric aerosol are generally close to log-normality (Georgopoulos and Seinfeld, 1982; Blackwood, 1991). In order to circumvent the bias due to incomplete time series, the variation of aerosol TM concentrations in time is presented by sorting the data into six groups, according to sampling dates: 1986-87, 1992-93, 1994-95, 1996-98, 2003-05 and 2006-08; TM concentration distributions of different groups were compared using a twosided t-test for unpaired samples. The 95\% confidence interval of the differences between group means and the corresponding p-values are accessible online: www.obsvlfr.fr/ heimbuerger/Files/stats2.pdf. Results indicate that $\mathrm{Al}, \mathrm{Fe}, \mathrm{Mn}, \mathrm{Ni}$ and $\mathrm{Cu}$ mean concentrations remained constant over the observed time period $(1986$ - 2008), since t-tests revealed no significant differences between the groups. Aluminium and Fe overall mean concentrations were $106 \pm 165$ and $138 \pm 132 \mathrm{ng} \mathrm{m}^{-3}$, respectively, representing by far the major mass fraction (>34 and $>45 \%$, respectively) of total measured TMs in the aerosol. High standard deviations confirm that Saharan dust inputs occur by pulses. However, maximum values, representing those strong Saharan dust inputs, are in the same order of magnitude, whatever the year. Similarly, Mn, Co, Ni and Cu mean concentrations remained constant all over the sampling period with values of $3.3 \pm 3.0,0.07 \pm 0.08$, $2.2 \pm 1.6$ and $3.9 \pm 3.3 \mathrm{ng} \mathrm{m}^{-3}$, respectively. Even though mean concentrations did not evolve over time, maximum values decreased continuously for $\mathrm{Cu}$, and minimum values decreased for $\mathrm{Ni}$.

Contrastingly, $\mathrm{Pb}, \mathrm{Cd}$ and $\mathrm{Zn}$ mean concentrations decreased over time. The most striking decrease occurred for $\mathrm{Pb}$. Lead aerosol concentrations remained constant from 1986 to 1993, with a geometric mean of roughly $30 \mathrm{ng} \mathrm{m}^{-3}$ (Table 3). A sharp decrease of 31\% was observed in 1994-95, down to $21.6 \mathrm{ng} \mathrm{m}^{-3}$. This trend continued in the following periods of 1996-98 and 2003-05, with decreases of $34 \%$ and $59 \%$, respectively, to levels of 14.4 and $5.8 \mathrm{ng} \mathrm{m}^{-3}$, respectively. In the most recent period, $\mathrm{Pb}$ aerosol concentrations continued to decrease, by 43\% between 2003-05 and 2006-08, down to concentrations of $3.33 \mathrm{ng} \mathrm{m}^{-3}$. In summary, $\mathrm{Pb}$ concentrations have decreased by $90 \%$ from 1986 to 2008. The amplitude of the variation of $\mathrm{Pb}$ mean concentrations (SD, min and max, Table 3) has also decreased in the same time. More details on the $\mathrm{Pb}$ data set from 1986 to 2005 can be found elsewhere (Migon et al., 2008).

Cadmium concentrations did not change from the beginning of the observation period until 1998, with a mean value of $0.27 \mathrm{ng} \mathrm{m}^{-3}$. In 2006-08, after a 8 year-long period without measurements, Cd mean concentrations have decreased by $66 \%$, from 0.27 to $0.09 \mathrm{ng} \mathrm{m}^{-3}$, and standard deviations and maximum values cut by two thirds as well (Table 3). Zinc exhibited a comparable trend as Cd. Zinc mean concentrations remained constant at approximately $23.9 \mathrm{ng} \mathrm{m}^{-3}$, from 1986 to 1998 . A steep decrease of 54\% was observed between 1998 and 2006-08, down to concentrations of $10.9 \mathrm{ng} \mathrm{m}^{-3}$. In addition to these long-term observations, short-term variations of TM in the aerosols have been studied during the 2006-08 period on a weekly basis (Fig. 2). It clearly appears that crustal elements ( $\mathrm{Al}, \mathrm{Fe}, \mathrm{Mn}$, and $\mathrm{Co}$ ) were more concentrated in the atmosphere during summer periods and less concentrated in winter, with a quite regular seasonal cycle. Anthropogenic elements (Pb, Cd and $\mathrm{Zn}$ ) also displayed significant short-term variations but no marked seasonal cycle appeared. Higher concentrations have occurred in the autumn 2007 and 2008 and in winter 2007-08. Nickel and Cu presented a mixed behaviour, with both crustal and anthropogenic patterns as described previously (Fig. 2).

\section{Discussion}

Trace metals can be ordered according to the nature of their emission sources. Table 3 gives the intercorrelation matrix for the analysed TMs. Three different groups can be distinguished. Alumium, $\mathrm{Fe}, \mathrm{Mn}$ and $\mathrm{Co}$, hereinafter referred to as crustal TMs, present a first group of highly intercorrelated 
elements. Lead, Cd and Zn form a second group of anthropogenic TMs, highly intercorrelated as well. Nickel and $\mathrm{Cu}$ seem to be intermediate between the two groups, since they are highly correlated, on the one hand with some crustal TMs and on the other hand with some anthropogenic TMs. We refer $\mathrm{Ni}$ and $\mathrm{Cu}$ hereinafter to as intermediate TMs and discuss their particular behaviour.

\subsection{Seasonal patterns}

Crustal TMs presented pronounced seasonal patterns with highest concentrations in summer and lowest in winter. On the contrary, anthropogenic TMs did not show a clear seasonal pattern. This has already been observed in the Eastern Mediterranean basin at sampling sites in proximity to crustal emission sources (Koçak et al., 2004). Soil-derived and/or Saharan emissions are characterised by high Al content, this TM being usually taken as the crustal reference (e.g., Wedepohl, 1995). To various extents, $\mathrm{Fe}, \mathrm{Mn}, \mathrm{Co}, \mathrm{Ni}$ and $\mathrm{Cu}$ also derive from crustal material, and they exhibit roughly similar seasonal patterns (Fig. 2). Saharan episodes generally occur in spring and summer (Moulin et al., 1997), as observed in our study. However, the occurrence of significant episodes at other periods of the year is not exceptional (Bonnet and Guieu, 2006). Therefore, it is not surprising to observe the most significant peaks of crustal TMs not only in July 2006 and June 2008, but also in autumn (October 2007 and 2008, Fig. 2).

In addition to this general pattern, common to all the crustal elements studied here (Al, Fe, Mn and $\mathrm{Co}$ ), intermediate TMs ( $\mathrm{Ni}$ and $\mathrm{Cu}$ ) presented high concentrations in aerosols collected in winter 2007-08. This "bump" was also present in the $\mathrm{Pb}, \mathrm{Cd}$ and $\mathrm{Zn}$ time-series (Fig. 2), suggesting anthropogenic sources for these events.

The anthropogenic component of $\mathrm{Ni}$ concentrations in marine environments is known substantial. In particular, oil combustion is responsible for spreading of significant amounts of Ni (Anwari et al., 1992; Chiffoleau et al., 2004). Major emissions of anthropogenic Ni sources, influencing the whole Mediterranean region, originate from Lebanon, Tunisia, Bulgaria and Cyprus (Pirrone et al., 1999). Saharan material also contains significant amounts of $\mathrm{Ni}$, as evidenced by relatively low enrichment factors normalised to Al in the North-western Mediterranean aerosol (Chester et al., 1984). Aeolian dust samples might also be enriched in North-western Mediterranean areas by the erosion (including anthropogenic landscaping) of serpentine, which is fairly abundant in regional soils, in particular North Corsica, which is approximately $175 \mathrm{~km}$ from our sampling station. To a lesser extent, this can be observed for $\mathrm{Cu}$. The relative importance of the crustal component in atmospheric $\mathrm{Cu}$ concentrations (up to $20 \%$ of total airborne $\mathrm{Cu}$ ) might be a peculiarity of the North-western Mediterranean region, as already observed in previous works based on Cap Ferrat atmospheric monitoring (Migon and Caccia, 1990; Migon et al., 1994). The Ligurian region might also be influenced by a point source of $\mathrm{Ni}$. In North-east Corsica (see Fig. 1), a chrysotile asbestos mine was operating until 1965 near the village of Canari and several zones with surface deposit of asbestos still remain. High $\mathrm{Ni}$ and chromium levels observed in mussels have been linked to waste from the disused mine (Andral et al, 2004). Lastly, the northern coast of the Ligurian Sea is strongly affected by seasonal cruising ships. However, the seasonal pattern exhibited by Ni concentrations in the aerosol (Fig. 2), with highest concentrations observed between May and November, suggests that the combination of Saharan crustal inputs and regional anthropogenic emissions such as cruise ships is the prevailing source of $\mathrm{Ni}$ to the coastal Ligurian atmospheric aerosol.

Nevertheless, Saharan inputs are also likely to bring relatively high amounts of anthropogenic material to North-western Mediterranean surface waters (Guieu et al., in press). This may partly explain that, in the present data set, relatively high concentrations of TMs of recognised anthropogenic character such as $\mathrm{Cd}$ or $\mathrm{Zn}$ are sometimes associated with Saharan dust events, concomitantly with high concentrations of crustal TMs such as $\mathrm{Al}, \mathrm{Fe}, \mathrm{Mn}$ and Co. (e.g. October $20^{\text {th }}$ 2008). There is a need, therefore, to tentatively allocate the so-called anthropogenic TMs to natural and anthropogenic emission sources. On the one hand, TMs classified as "anthropogenic" have also a natural component since they are present in trace amounts in lithogenic material. Such low concentrations may be counterbalanced by very high loads of material supplied by Saharan dust events. On the other hand, when Saharan air masses pass over polluted North-African cities, they may be significantly enriched by anthropogenic TM emissions. 
The anthropogenic component of aerosol samples can be assessed, using enrichment factors (EFs) standardised to $\mathrm{Al}$, which is the most commonly used soil dust reference. These ratios are usually defined for a given element $X$ as (e.g., Artaxo et al., 1990; Herut et al., 2001):

$\mathrm{EF}_{\mathrm{X}}=[(\mathrm{X}) /(\mathrm{Al})]_{\text {aerosol }} /[(\mathrm{X}) /(\mathrm{Al})]_{\text {soil dust }}$

where $(X)$ is the concentration of the element $X$ in the aerosol or the reference soil dust. Elemental mean concentrations in soil dust or in erodible rocks are very difficult to define accurately, due to inhomogeneous elemental composition of worldwide soils. Moreover, the ratio $[(\mathrm{X}) /(\mathrm{Al})]_{\text {soil dust }}$ may be dependent on grain size fractionation and chemical alteration during atmospheric transport. Such chemical modifications might involve solubilisation of certain TMs from particles, photo-chemically induced redox-reactions and aggregation processes (Desboeufs et al., 2001). One may infer that the use of EFs is questionable, therefore. However, their use is permissible if they are used for the comparison of different enrichments standardised to the same (Al) soil dust value (Herut et al., 2001).

Fig. 3 shows the seasonal variability of EFs during the 2006-08 period. Basically, high EFs for anthropogenic TMs correspond to low Al concentrations. Low EF values are generally observed during the period between May and November, which suggests that the enrichment of natural material by anthropogenic emissions during the transport of Saharan air masses is not significant. The very low EF values (Fig. 3) observed for the three most intense Saharan episodes during the period 200608, i.e., in decreasing order, October $20^{\text {th }} 2008$, October $3^{\text {rd }} 2007$ and July $4^{\text {th }} 2006$ (Fig. 2), may partly result from a "dilution effect" caused by the very high loads of Al. Keeping in mind that the three highest Al concentrations were found in samples that exhibited medium to high anthropogenic (e.g., $\mathrm{Cu}, \mathrm{Cd}, \mathrm{Zn}$ ) TM concentrations (Fig. 2), it is possible that EF values are distorted for the case of very intense Saharan events. However, the seasonal pattern of EFs for the case of anthropogenic TMs such as $\mathrm{Pb}, \mathrm{Cd}$ and $\mathrm{Zn}$ (Fig. 3) stresses the importance of anthropogenic sources on $\mathrm{Pb}, \mathrm{Cd}$ and $\mathrm{Zn}$ concentrations in the North-western Mediterranean atmospheric aerosol.

Anthropogenic inputs, originating generally from the North and the North-East, presumably prevail in winter, in agreement with advective transport of polluted air masses from Europe (Duncan and Bey, 2004). This can be observed, e.g., for Pb in January and February 2008, for Cd from December 2007 to March 2008, or for Zn in March 2008 (Fig. 2). This pattern is neither reproducible every year, nor for other TMs, however.

Significant anthropogenic inputs are also observed in autumn. Much more reproducible are the peaks observed in October (Fig. 2): all TMs that have a significant anthropogenic component ( $\mathrm{Ni}, \mathrm{Cu}, \mathrm{Pb}$, $\mathrm{Cd}$, and $\mathrm{Zn}$ ) exhibit significant peaks in this period, every year. These high anthropogenic TM concentrations are presumably associated with a change in the prevailing airflow rate, when the autumnal equinox points to the moving of the polar front to the southward and, thus, the arrival of air masses originating from northern and north-eastern industrialised regions of Europe to the Western Mediterranean. Satellite data show that the Ligurian Sea may be more strongly affected by anthropogenic land-based particulate emissions in the autumn than in the winter (Barnaba and Gobbi, 2004). In 2007 and 2008, high concentrations were observed for anthropogenic and crustal TMs as well. The reproducibility of this situation suggests that autumnal meteorological conditions might favour the mixing of Northern/North-eastern and Southern air masses. This may strengthen the statement that, apart from episodic Saharan episodes, the North-western Mediterranean background aerosol is dominated by anthropogenic emission sources.

The case of $\mathrm{Zn}$ is believed more specific: On the one hand, high concentrations are sometimes observed in summer, although they are not concomitant with the occurrence of high peaks of crustal TMs. On the second hand, a very high value was observed on December $4^{\text {th }} 2008$. Urban emission sources presumably give off amounts of $\mathrm{Zn}$, among which a great part comes from motor vehicle use, owing to tyre wear (Wiesner et al., 1998). The Ligurian Sea is subject to significant emission sources from the large urbanised area between Toulon and Genoa. In addition, $\mathrm{Zn}$ is believed significantly emitted by waste incinerations (Nriagu and Pacyna, 1988), which are probably a noticeable source of $\mathrm{Zn}$, particularly when waste plant residual muds are incinerated. Two waste incineration facilities are 
in the vicinity of Cap Ferrat, one mud incinerator at l'Ariane, roughly $10 \mathrm{~km}$ from the shoreline and an another urban incinerator at Antibes $38 \mathrm{~km}$ from the sampling site (Migon and Sandroni, 1999). Therefore, significant regional emission sources may be responsible for the peculiar pattern of $\mathrm{Zn}$ seasonal concentrations in the atmospheric aerosol. The exceptional event observed on 4 December 2008 is believed the signature of an accidental regional-scale contamination, but mere contamination cannot be discarded.

\subsection{Decadal trends}

\section{Crustal TMs (Al, Fe, Mn and Co)}

The main emission source of crustal TMs (Al, Fe, Mn and Co) in the Western Mediterranean is Saharan dust. Consistently, all these elements are characterized by high intercorrelation factors in our data set from $r=0.85$ (Al-Co) to $r=0.96$ (Al-Fe) (Table 3). Besides some interannual variation, Al aerosol concentrations remained overall stable (Fig. 4) with a geometric mean of $106 \pm 165 \mathrm{ng} \mathrm{m}^{-3}$. Such variability $(>150 \%)$ is probably inherent to the pulsed character of Saharan dust emissions, of which interannual variations are mainly due to changes in the occurrence of the most intense dust events, i.e. the frequency of dust events rather than their intensity (Marticorena and Bergametti, 1996).

There is a strong similarity between Al and Fe for the groups 1994-95, 1997-98 and 2006-08. As well, the observed variability from a year to another should be attributed to the pulsed character of Saharan events. For example, Bonnet and Guieu (2006) attributed up to 99\% of the total 2004 flux of total atmospheric Fe at Cap Ferrat to these few strong pulses of Saharan dust events. Since the high 2004 loads of Fe were not followed in 2006-08 by any noticeable increase of Al and Fe inputs, it is very likely that the strong events observed in 2004 should be ascribed to the natural variability of such pulsed inputs, as already pointed out by other studies (e.g., Marticorena and Bergametti, 1996).

Cobalt and Mn exhibit the same temporal trend, which is essentially due to interannual variability. Such decadal patterns suggest that no significant trend arises. Some papers suggest an increase of the frequency of Saharan events in Mediterranean regions (e.g., Avila and Peñuelas, 1999; Rogora et al., 2004), while others predict worldwide decrease of dust events (e.g., Mahowald and Luo, 2003). This is not observed here (Fig. 4), however.

\section{Intermediate TMs (Ni and Cu)}

Nickel and $\mathrm{Cu}$ aerosol concentration at Cap Ferrat remained stable over the past two decades. Pirrone et al. (1999) predicted an increasing trend for $\mathrm{Ni} \mathrm{(+44 \% )}$ and a slight increase of Cu aerosol concentrations (+4.5\%) in the Mediterranean region from 1985 until 2010 . We did not observe any change in $\mathrm{Ni}$ aerosol concentrations, while $\mathrm{Cu}$ aerosol concentrations are roughly consistent with those predictions. Oil combustion is still the major source (1998 estimate) of Ni released in the atmosphere (Pirrone et al., 1999).

Copper emissions in France are almost entirely owed to brake wear of road vehicles and the wear of trolley wires from railways, with increasing trend in both sectors. However, the overall Cu emissions in France remain stable (CITEPA, 2009). Copper aerosol concentrations in the 1980s in the Western Mediterranean area were in the range of 2.5-3.2 $\mathrm{ng} \mathrm{m}^{-3}$ (UNEP, 1991). Our measurements of $\mathrm{Cu}$ aerosol concentrations at Cap Ferrat were in the same order of magnitude, with most recent values of $3.81 \mathrm{ng} \mathrm{m}^{-3}$ in the period of 2006-08. The case of $\mathrm{Cu}$ might be a peculiarity of North-western Mediterranean region, e.g. at Cap Ferrat, the anthropogenic contribution of atmospheric particulate $\mathrm{Cu}$ is rather weak. There are apparently very few close sources and the most significant contribution is probably due to long-range transport (Migon and Caccia, 1990). Libya is the major emitter of Cu in the Mediterranean region (Pirrone et al., 1999) and $\mathrm{Cu}$ emissions might thus be associated to southerly crustal inputs, such as Saharan dust events. 
Atmospheric inputs of TMs released to the Mediterranean basin by atmospheric deposition and wet scavenging by precipitation are primarily due to industrial and urban emissions and Saharan dust loads (EEA, 1997). The combustion of fossil fuels, non-ferrous metal smelters and waste incineration represent important sources of $\mathrm{Pb}, \mathrm{Ni}, \mathrm{Cu}$ and $\mathrm{Cd}$ in the Mediterranean region as a whole. Anthropogenic emissions for those TMs are considered several orders of magnitude higher than the contributions from natural sources (Pirrone et al., 1999).

Emissions of TMs can be characterised by the use of TM emission factors for specific sources and direct measurements of TM concentrations in the atmosphere. Trace metal emissions estimated by the use of TM emission factors might be afflicted with a considerable uncertainty, above all those of waste incinerators, but often represent the only approach to access TM emissions on a global scale. Pirrone et al. (1999) predicted trends for the Mediterranean region from 1985 until 2010 based on emission factors: $\mathrm{Pb}(-67 \%)$ and $\mathrm{Cd}(-6 \%)$. Our aerosol measurements are in agreement with those predictions: $\mathrm{Pb}, \mathrm{Cd}$ (and $\mathrm{Zn}$ ) aerosol concentrations decreased remarkably over the last 23 years.

The case of $\mathrm{Pb}$ at the Cap Ferrat sampling site over the period 1986-2005 was already described by Migon et al. (2008), readers may find detailed information therein. Briefly, tetra-ethyl $\mathrm{Pb}$ was used until the 1990s as an additive in gasoline to increase its octane rating (Kummer et al., 2009). In the 1970s, the German government was the first in Europe to regulate lead additives in gasoline (Pacyna et al., 2009). Various EU directives have limited the Pb content of gasoline since. Gasoline and diesel combustion were still considerable $\mathrm{Pb}$ emission sources, because antipollution policies concerned primarily organic $\mathrm{Pb}$ additives, which were restricted in the $\mathrm{EU}$, but not the natural $\mathrm{Pb}$ content, inherent to the crude oil (Pirrone et al., 1999). Since 2002, the main source of Pb emission was the manufacturing industry, mainly from iron and steel industry and the processing of non-metallic minerals and construction materials. The broadening of the implementation of these antipollution policies on leaded petrol over Europe yielded a significant decrease of $\mathrm{Pb}$ aerosol concentrations in the Western Mediterranean troposphere (Migon et al., 1993, 2008; Pirrone et al., 1999; Miralles et al., 2006). Our most recent measurements reveal a further decrease since the measurements of 2005 from 5.87 to $3.33 \mathrm{ng} \mathrm{m}^{-3}$ (Table 2).

Cadmium aerosol concentrations in the Western Mediterranean in the 1980s were in the range of 0.8$2.0 \mathrm{ng} \mathrm{m}^{-3}$ (UNEP, 1991). Our measurements during this time at the Cap Ferrat sampling site were significantly lower, with a geometric mean of $0.27 \mathrm{ng} \mathrm{m}^{-3}$. Based on present observations, Cd aerosol concentrations at Cap Ferrat remained constant until 1998. Cadmium mean concentrations have steeply decreased by $66 \%$ to levels of $0.09 \mathrm{ng} \mathrm{m}^{-3}$ in 2006-08. This is in agreement with studies of Pacyna et al. (2009), who stated that total atmospheric Cd emissions in Europe decreased by $80 \%$ over the last 40 years. Cadmium emissions in France were reduced by $82 \%$ since 1990, explained mainly by improvements in industrial sectors such as iron and steel industry, non-ferrous smelters and removal of pollutants from the flue gases generated by household waste incineration plants (CITEPA, 2009).

Zinc aerosol concentrations at Cap Ferrat decreased by $54 \%$ over the last decade. In addition to the above-mentioned urban $\mathrm{Zn}$ emission sources (Wiesner et al., 1998) and waste incineration (Migon and Sandroni, 1999; Nriagu and Pacyna, 1988; Pacyna, 1984), other major Zn emissions sources are the manufacturing industry and wood consumption. Zinc emissions in France decreased by $89 \%$ since 1990, mainly caused by technical improvements in electric furnace steel plants, i.e. the installation of dust extractors (CITEPA, 2009) and the implementation of the European directive on waste incineration (Directive 2000/76/CE, 2000), limiting Zn emissions from that particular source.

\section{Conclusion}

The present work demonstrates that, despite increasing anthropogenic pressure in Europe, the implementation of antipollution policies yielded an actual decrease of anthropogenic TMs in the atmosphere. We observed a rapid response of anthropogenic TM aerosol concentrations to the restriction of emissions. On the contrary, crustal TMs did not show any trend during the last two 
decades despite global climate change, which has a strong impact on the meteorological settings of the Mediterranean region (Béthoux et al., 1998).

Our findings underline the importance of environmental monitoring during this transition from national to intergovernmental environmental management leading to manifold antipollution policies and directives. Long-term environmental monitoring leads, on the one hand, through the understanding of the impact of certain contaminants, to new directives and, on the other hand, is the tool to evaluate the response of the environment to those directives.

Further research should address the impact of the change in aerosol quality on the environment, e.g. cycling of those TMs in the Mediterranean, and a conclusive understanding of the respective natural and anthropogenic fractions of various TMs.

\section{Acknowledgements}

This work was partly supported by the Conseil Général des Alpes-Maritimes (project AIRMED 06) and with the partnership of the Agence de l'Eau Rhône Méditerranee Corse (Rhône-MediterraneanCorsica Water Agency). We wish to thank Dominique Auger and Emmanuelle Rozuel for their valuable assistance with sample preparation and logistics, and Bernard Gentili for technical assistance. We are also indebted to the Université de Nice-Sophia Antipolis. We also wish to thank the French Marine team of the Cap Ferrat naval signal station. Lastly, we are grateful for the constructive review comments which greatly improved this manuscript.

\section{References}

Andral, B, Stanisiere JY, Sauzade D, Damier E, Thebault H, Galgani F, Boissery P. Monitoring chemical contamination levels in the Mediterranean based on the use of mussel caging. Mar Pollut Bull 2004;49(9-10):704-712.

Anwari MA, Tuncel G, Ataman OY. Lead and nickel levels in Black Sea aerosols by ETA-AAS. Intern J Environ Anal Chem 1992;47:227-37.

Artaxo P, Maenhaut W, Storms H., van Grieken R. Aerosol characteristics and sources for the Amazon basin during the wet season. J Geophys Res 1990;95:16971-85.

Avila A, Peñuelas J. Increasing frequency of Saharan rains over northeastern Spain and its ecological consequences. Sci Total Environ 1999;228:153-56.

Barnaba F, Gobbi GP. Aerosol seasonal variability over the Mediterranean region and relative impact of maritime, continental and Saharan dust particles over the basin from MODIS data in the year 2001. Atmos Chem Phys 2004;4:2367-91.

Béthoux JP, Gentili B, Morin P, Nicolas E, Pierre C, Ruiz-Pino D. The Mediterranean Sea: a miniature ocean for climatic and environmental studies and a key for the climatic functioning of the North Atlantic. Progr Oceanogr 1999;44:131-146.

Béthoux JP, Gentili B, Tailliez D. Warming and freshwater budget change in the Mediterranean since the 1940s, their possible relation to the greenhouse effect. Geophys Res Lett 1998;25:1023-1026. 
Béthoux JP, Morin P, Ruiz-Pino D. Temporal trends in nutrient ratios: chemical evidence of Mediterranean ecosystem changes driven by human activity. Deep-Sea Research II 2002;49, 20072016.

Blackwood LG. The quality of mean and variance estimates for normal and lognormal data when the underlying distribution is misspecified. J Chemometrics 1991;5:263-71.

Bonnet S, Guieu C. Atmospheric forcing on the annual iron cycle in the western Mediterranean Sea: A 1-year survey. J Geophys Res 2006;111:C09010.

Centre Interprofessionnel Technique d'Etudes de la Pollution Atmosphérique (CITEPA), AIR EMISSIONS IN FRANCE, Mainland France, Substances relative to the contamination by heavy metals, www.citepa.org/emissions/nationale/ML/Emissions_FRmt_MLEN.pdf, date of access july 2009

Chester, R, Nimmo M and Corcoran PA. Rain water aerosol trace metal relationships at Cap Ferrat: A coastal site in the western Mediterranean. Mar Chem 1997; 58 (3-4): 293-312.

Chester R, Nimmo M, Preston MR. The trace metal chemistry of atmospheric dry deposition samples collected at Cap Ferrat: a coastal site in the Western Mediterranean. Mar Chem 1999; 68:15-30.

Chester R, Sharples EJ, Sanders GS. Saharan dust incursion over the Tyrrhenian Sea. Atmos Environ 1984;18:929-35.

Chiffoleau JF, Chavaud L, Amouroux D, Barats A, Dufour A, Pécheyran C, Roux N. Nickel and vanadium contamination of benthic invertebrates following the "Erika" wreck. Aquat Living Resour 2004;17:273-80.

Desboeufs KV, Losno R and Colin JL. Factors influencing aerosol solubility during cloud processes. Atmos Environ 2001;35(20):3529-3537.

Directive 2003/17/EC. Directive of the European Parliament and of the Council of 3 March 2003, amending Directive 98/70/EC relating to the quality of petrol and diesel fuels, Brussels; 2003.

Directive 2000/76/EC. Directive of the European Parliament and of the Council of 4 December 2000 on the incineration of waste, Brussels; 2000.

Duncan BN, Bey I. A modelling study of the export pathways of pollution from Europe: seasonal and interannual variations (1987-1997). J Geophys Res 2004;109:D08301.

EEA (European Environment Agency). Europe's Environment. The Dobris Assessment, David Stanners and Philippe Bourdeau (eds.) 1997.

Georgopoulos P, Seinfeld JH. Statistical distributions of air pollutant concentrations. Environ Sci Technol 1982;16:27-35.

Guerzoni S, Chester R, Dulac F, Herut B, Loÿe-Pilot MD, Measures C, Migon C, Molinaroli E, Moulin C, Rossini P, Saydam C, Soudine A, Ziveri P. The role of atmospheric deposition in the biogeochemistry of the Mediterranean Sea. Progr Oceanogr 1999;44:147-190.

Guieu C, Loÿe-Pilot MD, Benyahya L, Dufour A. Spatial variability of atmospheric fluxes of metals (Al, $\mathrm{Fe}, \mathrm{Cd}, \mathrm{Zn}$ and $\mathrm{Pb}$ ) and phosphorus over the whole Mediterranean from a one-year monitoring experiment; biogeochemical implications. Mar Chem in press. 
Güllü GH, Olmez I, Tuncel G. Temporal variability of atmospheric trace element concentrations over the eastern Mediterranean Sea. Spectrochim Acta Part B 2000;55:1135-50.

Herut B, Nimmo M, Medway A, Chester R, Krom MD. Dry atmospheric inputs of trace metals at the Mediterranean coast of Israel (SE Mediterranean): sources and fluxes. Atmos Environ 2001;35(4):803-813

Idardare Z, Chiffoleau JF, Moukrim A, Alla AA, Auger D, Lefrere L and Rozuel E. Metal concentrations in sediment and Nereis diversicolor in two Moroccan lagoons: Khnifiss and Oualidia. Chem and Ecol 2008;24(5): 329-340.

Jickells TD. Atmospheric inputs of metals and nutrients to the oceans: their magnitude ad effects. Mar Chem 1995;48:199-214.

Koçak M, Nimmo M, Kubilay N, Herut B. Spatio-temporal aerosol trace metal concentrations and sources in the Levantine Basin of the Eastern Mediterranean. Atmos Environ 2004;38(14):2133-2144.

Kummer U, Pacyna JM, Pacyna EG, Friedrich R. Assessment of heavy metal releases from the use phase of road transport. Atmos Environ 2009;43:640-47.

Marticorena B, Bergametti G. Two-year simulations of seasonal and interannual changes of the Saharan dust emissions. Geophys Res Lett 1996;23:1921-24.

Mahowald NM, Luo C. A less dusty future? Geophys Res Lett 2003; 30(17):4.

Migon C, Alleman L, Leblond, N, Nicolas E. Evolution of atmospheric lead in northwestern Mediterranean between 1986 and 1992. Atmos Environ 1993a;27A:2161-67.

Migon C, Courau P and Gentili B. Determination of atmospheric aluminium by graphite furnace atomic absorption spectrophotometry under $\mathrm{Ar}+\mathrm{CH} 4$ flow. Intern J Environ Anal Chem 1993b;50:183-191.

Migon C, Caccia JL. Separation of anthropogenic and natural emissions of particulate heavy metals in the western Mediterranean atmosphere. Atmos Environ 1990;24A:399-405.

Migon C, Gentili B, Journel B. Statistical analysis of the concentrations of twelve metals in the Ligurian atmospheric aerosol. Oceanol Acta 2000;23(1):37-45.

Migon C, Jourdan E, Nicolas E, Gentili B. Effects of reduced leaded fuel consumption on atmospheric lead behaviour. Chemosphere 1994;28:139-44.

Migon C, Robin T, Dufour A, Gentili B. Decrease of lead concentrations in the Western Mediterranean atmosphere during the last 20 years. Atmos Environ 2008;42:815-21.

Migon C, Sandroni V. Phosphorus in rainwater: Partitioning inputs and impact on the surface coastal ocean. Limnol Ocean 1999;44(4):1160-1165.

Miralles J, Véron AJ, Radakovitch O, Deschamps P, Tremblay T, Hamelin B. Atmospheric lead fallout over the last century recorded in Gulf of Lions sediments (Mediterranean Sea). Mar Pollut Bull 2006;52:1364-71.

Moulin C, Lambert CE, Dulac F, Dayan U. Control of atmospheric export of dust from North Africa by the North Atlantic oscillation. Nature 1997;387:691-94.

Nicolas E, Migon C, Leblond N, Journel B. Seasonality of dry and wet deposition of trace metals in the Ligurian Sea. Wat Pollut Res Reports 1995;32:275-285. 
Nriagu JO, Pacyna JM. Quantitative assessment of worldwide contamination of air, water and soils by trace metals. Nature 1988; 333:134-139.

Pacyna JM, Pacyna EG, Aas W. Changes of emissions and atmospheric deposition of mercury, lead, and cadmium. Atmos Environ 2009;43:117-27.

Pacyna JM. Estimation of the atmospheric emissions of trace-elements from anthropogenic sources in Europe. Atmos Environ 1984;18(1): 41-50.

Pirrone N, Costa P, Pacyna JM. Past, current and projected atmospheric emissions of trace elements in the Mediterranean region. Wat Sci Technol 1999;39:1-7.

Rogora M, Mosello R, Marchetto A. Long-term trends in the chemistry of atmospheric deposition in Northwestern Italy: the role of increasing Saharan dust deposition. Tellus 2004;56B:426-34.

Sandroni V, Migon C. Atmospheric deposition of metallic pollutants over the Ligurian Sea: labile and residual inputs. Chemosphere 2002;47(7):753-64.

UNEP (United Nations Environment Programme). Airborne Pollution of the Mediterranean Sea of Land-Based Sources (Annex IV). Joint Meeting of the Scientific and technical Commitee and the Socio-Economic Commitee, 1991;UNEP (OCA) MED W.G: 25.

Wedepohl KH. The composition of the continental crust. Geochim Cosmochim Acta 1995;59:1217-32.

Wiesner MR, Characklis GW, Brejchova D. Metals and colloids in urban runoff. In: Allen HE, Garrison AW, Luther III GW, editors. Metals in Surface Waters. Ann Harbor Press. 1998;23-35.

World Meteorological Organization. Atmospheric transport of contaminants into the Mediterranean region. GESAMP Report 26, 53pp; 1985.

Zhang GS, Zhang J, Liu SM. Chemical composition of atmospheric wet deposition from the Yellow Sea and East China Sea. Atmos Res 2007;85:84-97. 


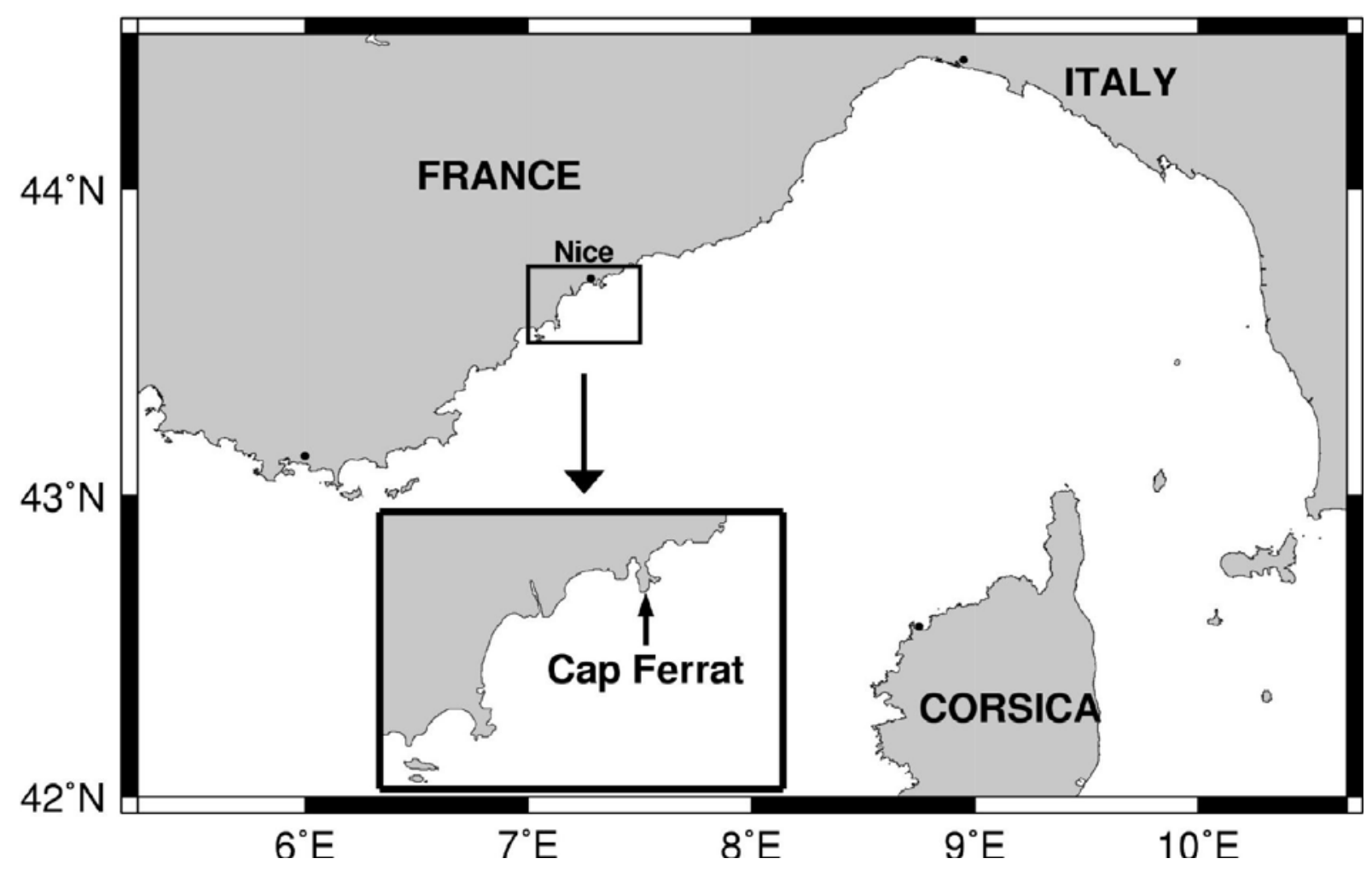

Figure 1: Location of the Cap Ferrat sampling station. 

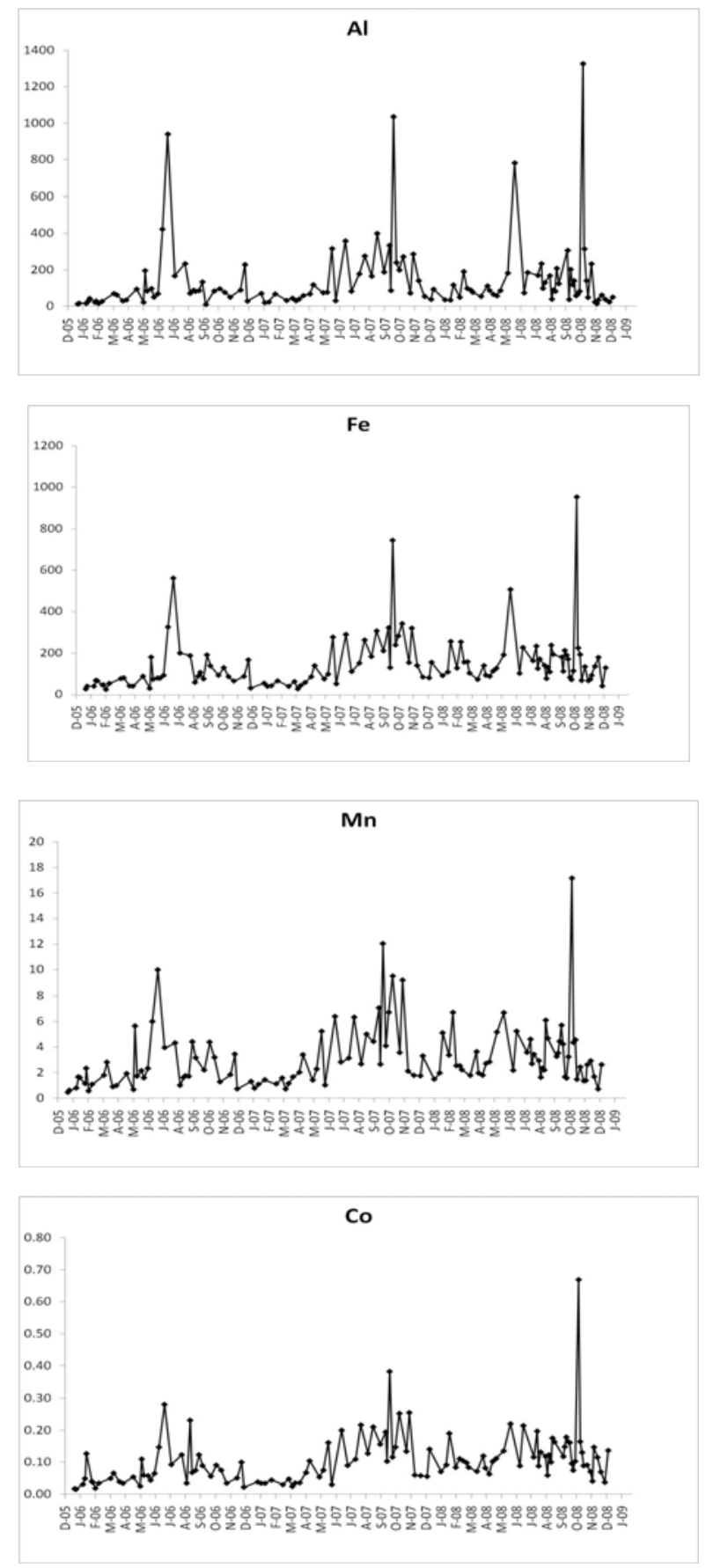
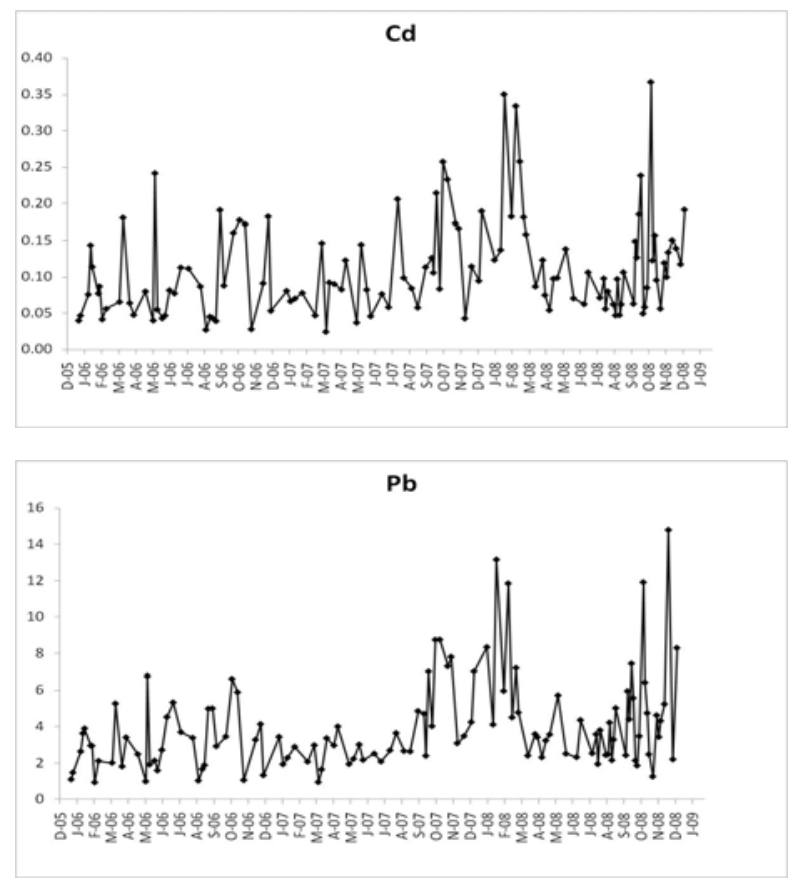

Figure 2

Figure 2: Seasonal variability of TM aerosol concentrations [ng $\mathrm{m}^{-3}$ ] from January 2006 to December 2008 

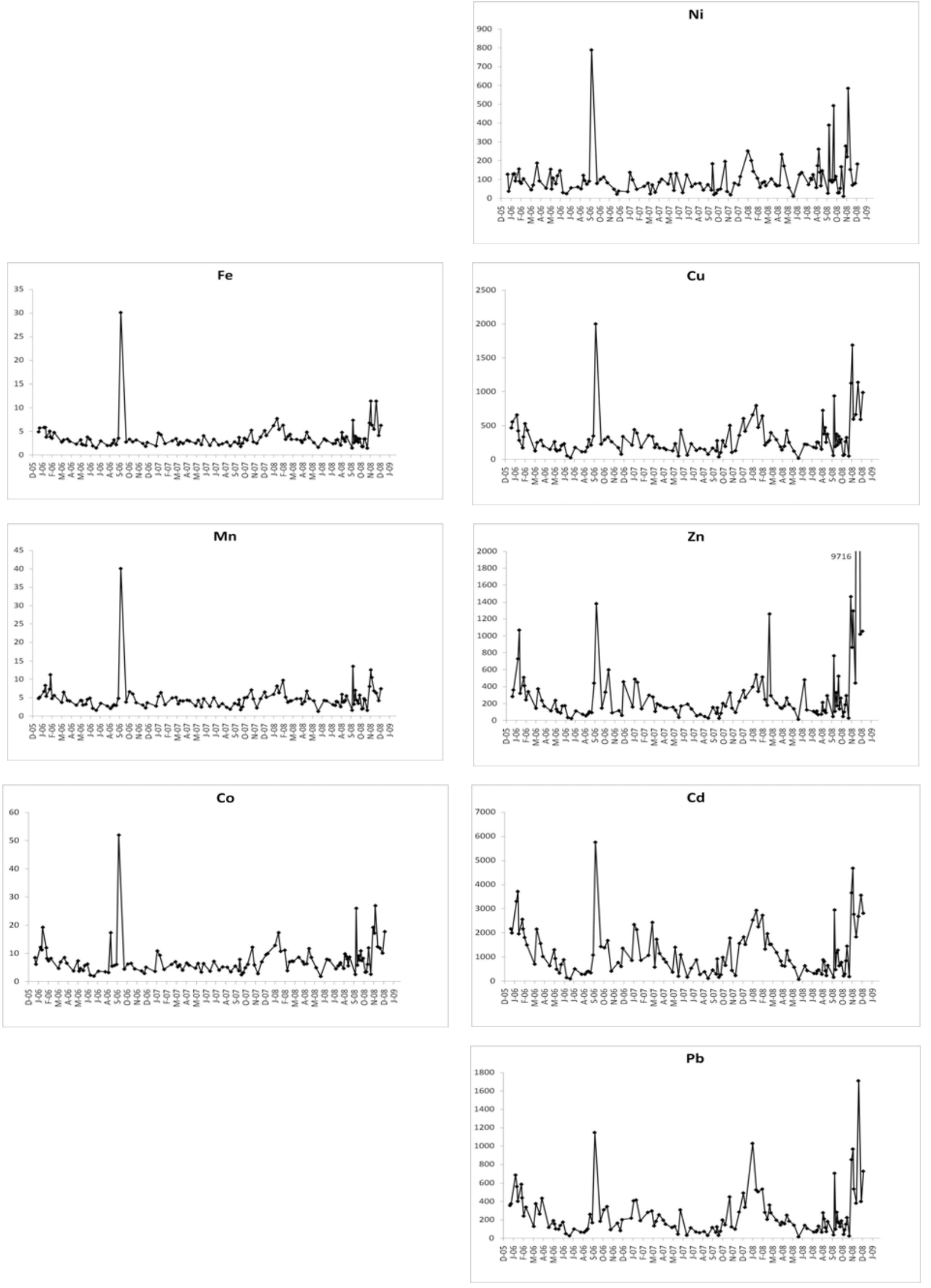

Figure 3

Figure 3: Seasonal variability of EFs normalised to Al from January 2006 to December 2008 

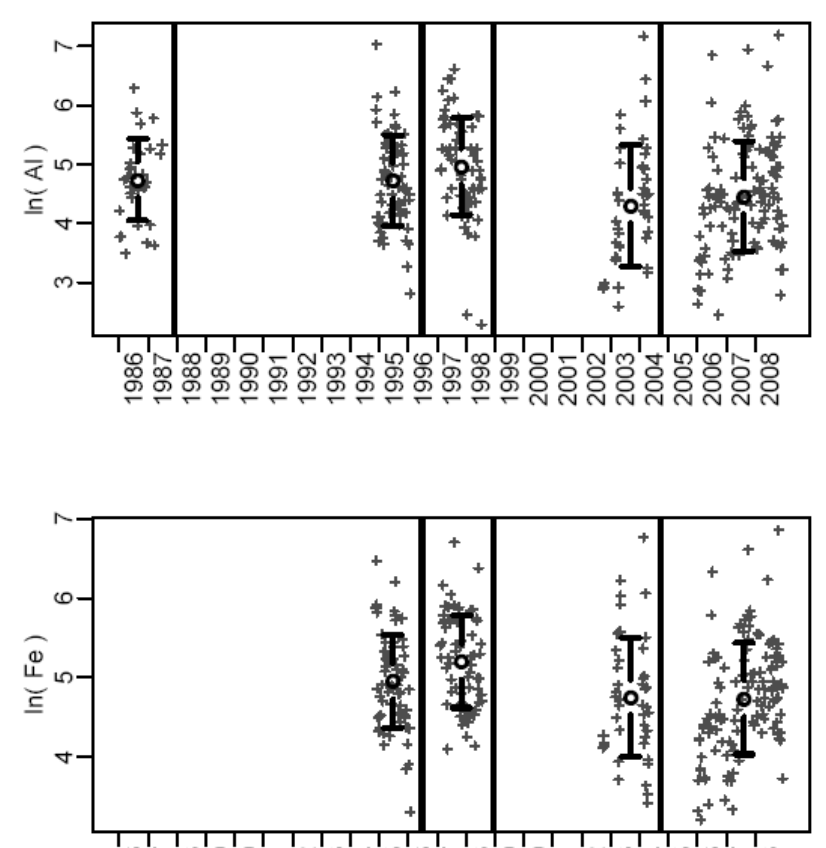

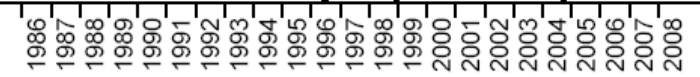

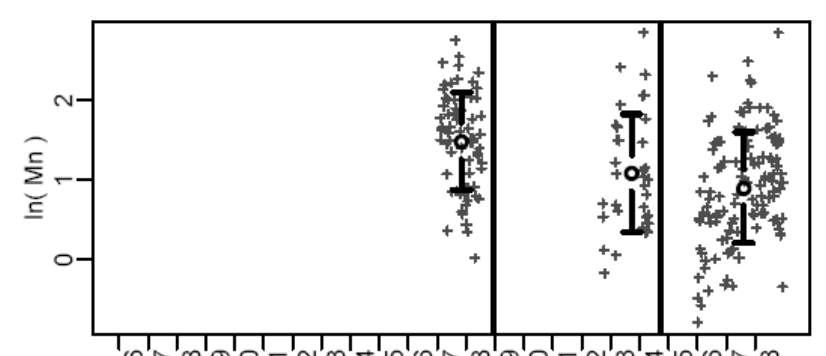

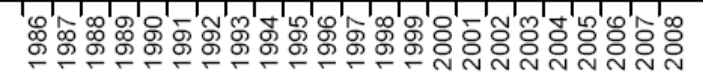

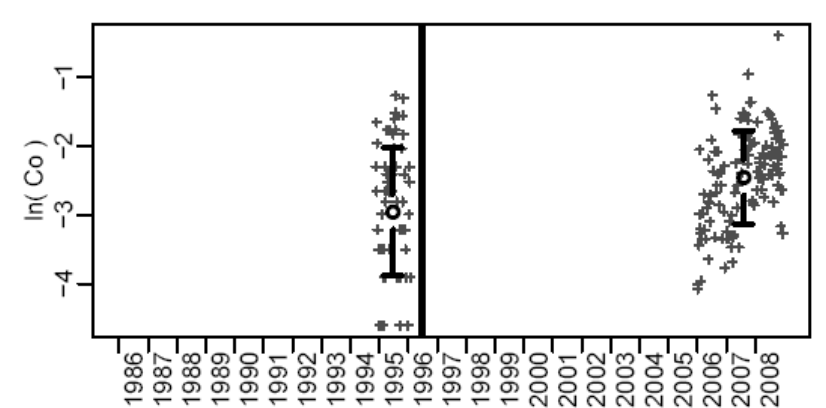

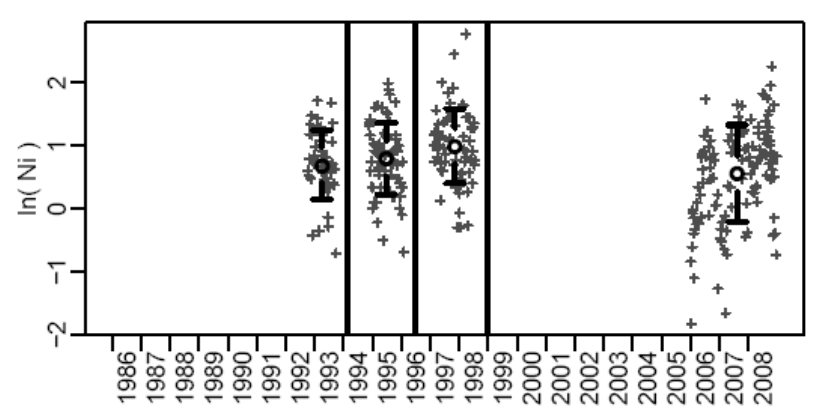
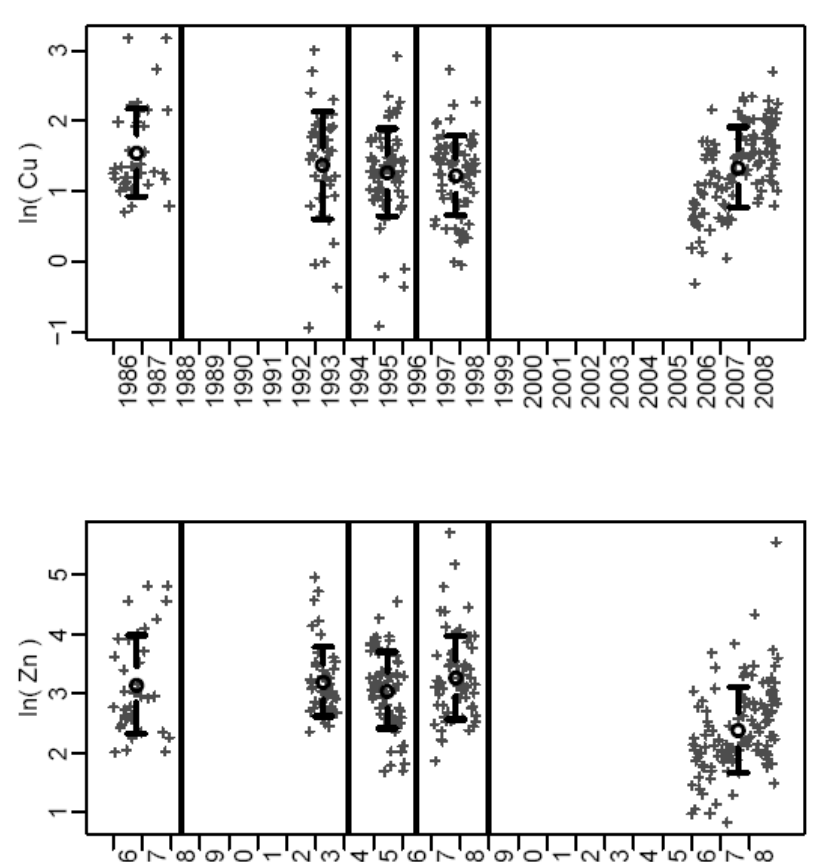

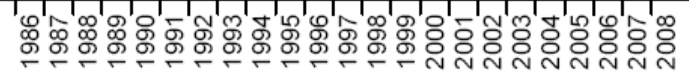
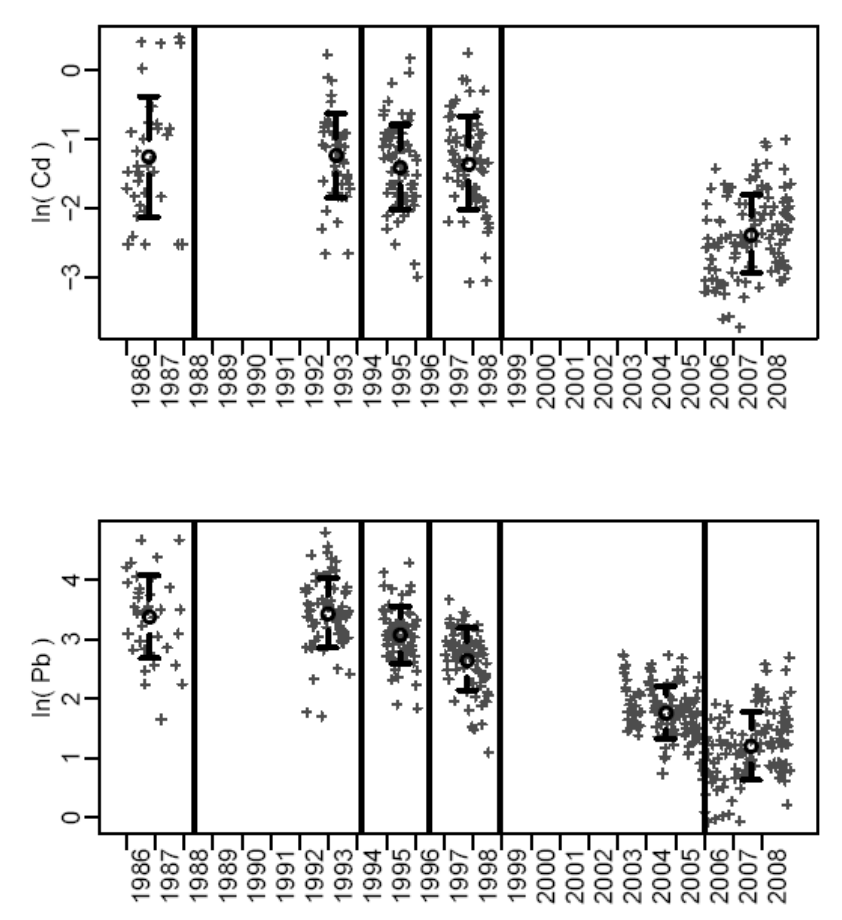
Figure 4: Interannual and decadal trends of TM aerosol concentrations [ng $\mathrm{m}^{-3}$ ] from January 2006 to December 2008

Tables

\begin{tabular}{|c|c|c|c|c|}
\hline TM & $\begin{array}{l}\text { Analytical } \\
\text { method }\end{array}$ & $\begin{array}{c}\text { Period of } \\
\text { application }(y r)\end{array}$ & $\begin{array}{l}\text { Detection limit } \\
\quad\left(\mathrm{ng} \mathrm{L}^{-1}\right)\end{array}$ & Reference \\
\hline \multirow[t]{2}{*}{ 4.1. $\mathrm{Al}$} & GFAAS $^{1}$ & $1986-87$ & $80 \mathrm{pg}^{\star}$ & Migon et al. (1993b) \\
\hline & ICP-AES $^{2}$ & 1994-2008 & 1500 & Migon et al. (2000) \\
\hline $\mathrm{Fe}$ & $\mathrm{ICP}-\mathrm{AES}^{2}$ & 1994-2008 & 600 & Migon et al. (2000) \\
\hline \multirow[t]{2}{*}{ Mn } & ICP-AES $^{2}$ & 1996-2004 & 900 & Migon et al. (2000) \\
\hline & $\mathrm{ICP}-\mathrm{MS}^{3}$ & $2006-08$ & 5 & this study \\
\hline \multirow[t]{2}{*}{ Co } & DPSAV $^{4}$ & $1994-96$ & 2 & Migon et al. (1997) \\
\hline & $\mathrm{ICP}-\mathrm{MS}^{3}$ & $2006-08$ & 1 & this study \\
\hline \multirow[t]{2}{*}{$\mathrm{Ni}$} & DPASV & $1992-98$ & 3 & Migon et al. (1997) \\
\hline & ICP-MS ${ }^{3}$ & $2006-08$ & 8 & this study \\
\hline \multirow[t]{3}{*}{$\mathrm{Cu}$} & GFAAS $^{1}$ & $1986-87$ & $13 \mathrm{pg}^{\star}$ & \multirow{2}{*}{$\begin{array}{c}\text { Migon and Caccia } \\
(1990)\end{array}$} \\
\hline & DPASV & $1992-98$ & 20 & \\
\hline & $\mathrm{ICP}-\mathrm{MS}^{3}$ & $2006-08$ & 5 & $\begin{array}{l}\text { Migon et al. (1997) } \\
\text { this study }\end{array}$ \\
\hline \multirow[t]{3}{*}{$\mathrm{Zn}$} & GFAAS $^{1}$ & $1986-87$ & $25 \mathrm{pg}^{\star}$ & \multirow{2}{*}{$\begin{array}{c}\text { Migon and Caccia } \\
(1990)\end{array}$} \\
\hline & DPSAV $^{4}$ & 1992-98 & 20 & \\
\hline & ICP-MS ${ }^{3}$ & $2006-08$ & 9 & $\begin{array}{c}\text { Migon et al. (1997) } \\
\text { this study }\end{array}$ \\
\hline \multirow[t]{3}{*}{ Cd } & GFAAS $^{1}$ & $1986-87$ & $0.2 \mathrm{pg}^{\star}$ & \multirow{2}{*}{$\begin{array}{c}\text { Migon and Caccia } \\
(1990)\end{array}$} \\
\hline & DPSAV $^{4}$ & $1992-98$ & 1 & \\
\hline & ICP-MS ${ }^{3}$ & $2006-08$ & 1 & $\begin{array}{c}\text { Migon et al. (1997) } \\
\text { this study }\end{array}$ \\
\hline \multirow[t]{4}{*}{$\mathbf{P b}$} & GFAAS $^{1}$ & $1986-87$ & $50 \mathrm{pg}^{\star}$ & \multirow{2}{*}{$\begin{array}{c}\text { Migon and Caccia } \\
(1990)\end{array}$} \\
\hline & DPSAV $^{4}$ & $1992-93$ & 2 & \\
\hline & GFAAS $^{1}$ & 1995-2005 & $50 \mathrm{pg}^{\star}$ & Migon et al. (1997) \\
\hline & ICP-MS ${ }^{3}$ & $2006-08$ & 2 & $\begin{array}{l}\text { Migon et al. (2008) } \\
\text { this study }\end{array}$ \\
\hline
\end{tabular}


Table 1: Summary of the different analytical techniques used between 1986 and 2008 for the determination of trace metal concentrations in the atmospheric aerosol, with the associated detection limits.

1.1986-87 measurements were performed with a Varian Techtron AA 1275 equipped with a CRA 90 atomiser and Ultra Carbon pyrolytic crucibles. From 1995 analysis were performed with Varian SpectroAA 800 with ZEEMAN correction and autosampler 2. Measurements were performed with a Jobin-Yvon JY 138 S Ultrace analyser, equipped with a Scott nebuliser. 3. Thermo Electron, $X$ series, analytical details are given in Idardare et al. 2008. 4. EG\&G Princeton Applied Research 264 A polarographic analysed coupled to a $303 \mathrm{~A}$ static $\mathrm{Hg}$ drop electrode $\left(1.6 \mathrm{~mm}^{2}\right.$ area). The auxiliary electrode was a Pt wire, and the $\mathrm{Ag} / \mathrm{AgCl}$ reference electrode was filled with a saturated solution of ultrapure $\mathrm{KCl}$. For $\mathrm{Cd}$ and $\mathrm{Pb}$, a glassy carbon rotating electrode (Tokay, $6 \mathrm{~mm}$ in diameter) was used as the working electrode. The measurements were performed with a Tacussel polarographic equipment (PRG-5 polarograph, fitted with two rotating EDI-type electrodes, with automatic Polaromate).The supporting electrolyte was seawater carried over a Chelex 100 resin (cation exchanger). Standard electrolysis times ranged between 3 min ( $\mathrm{Zn})$ and $10 \mathrm{~min}(\mathrm{Cd}$ and $\mathrm{Pb})$. In every case, the detection limit was the smallest readable signal, arbitrarily evaluated to $1 \mathrm{~mm}$.

*GFAAS measurements were carried out on sections of the membrane filter ( $3 \mathrm{~mm}$ in diameter) punched out and directly introduced into the carbon-rod atomiser, without any mineralisation. Detection limits are therefore expressed in mass instead of concentration units.

\begin{tabular}{|c|c|c|c|c|c|c|c|}
\hline & & $1986-87$ & $1992-93$ & 1994-95 & 1996-98 & 2003-05 & 2006-08 \\
\hline \multirow{6}{*}{ Al } & Geometric mean & 114 & & 113 & 143 & 74 & 86 \\
\hline & Arithmetic mean & 144 & & 154 & 192 & 135 & 140 \\
\hline & sd & 109 & & 158 & 151 & 216 & 191 \\
\hline & $\min$ & 33 & & 17 & 10 & 13 & 12 \\
\hline & $\max$ & 541 & & 1125 & 746 & 1298 & 1327 \\
\hline & $\mathrm{n}$ & 32 & & 67 & 69 & 44 & 119 \\
\hline \multirow{6}{*}{$\mathrm{Fe}$} & Geometric mean & & & 142 & 181 & 116 & 114 \\
\hline & Arithmetic mean & & & 168 & 215 & 158 & 147 \\
\hline & sd & & & 109 & 135 & 155 & 131 \\
\hline & $\min$ & & & 27 & 60 & 31 & 25 \\
\hline & $\max$ & & & 647 & 816 & 865 & 954 \\
\hline & $\mathrm{n}$ & & & 67 & 67 & 44 & 119 \\
\hline \multirow{6}{*}{ Mn } & Geometric mean & & & & 4.42 & 2.96 & 2.47 \\
\hline & Arithmetic mean & & & & 5.25 & 3.94 & 3.14 \\
\hline & sd & & & & 3.07 & 3.45 & 2.47 \\
\hline & $\min$ & & & & 1.02 & 0.84 & 0.46 \\
\hline & $\max$ & & & & 15.7 & 17.2 & 17.2 \\
\hline & $\mathrm{n}$ & & & & 68 & 37 & 119 \\
\hline \multirow{6}{*}{ Co } & Geometric mean & & & 0.05 & & & 0.09 \\
\hline & Arithmetic mean & & & 0.08 & & & 0.11 \\
\hline & sd & & & 0.07 & & & 0.08 \\
\hline & $\min$ & & & 0.01 & & & 0.02 \\
\hline & $\max$ & & & 0.28 & & & 0.67 \\
\hline & $\mathrm{n}$ & & & 67 & & & 119 \\
\hline \multirow{6}{*}{$\mathrm{Ni}$} & Geometric mean & & 1.98 & 2.20 & 2.69 & & 1.74 \\
\hline & Arithmetic mean & & 2.27 & 2.57 & 3.23 & & 2.25 \\
\hline & sd & & 1.16 & 1.46 & 2.39 & & 1.58 \\
\hline & $\min$ & & 0.49 & 0.50 & 0.74 & & 0.16 \\
\hline & $\max$ & & 5.53 & 7.3 & 15.9 & & 9.52 \\
\hline & $\mathrm{n}$ & & 48 & 67 & 69 & & 119 \\
\hline \multirow[t]{2}{*}{$\mathrm{Cu}$} & Geometric mean & 4.69 & 3.94 & 3.54 & 3.39 & & 3.81 \\
\hline & Arithmetic mean & 5.91 & 4.94 & 4.22 & 3.94 & & 4.45 \\
\hline
\end{tabular}




\begin{tabular}{|c|c|c|c|c|c|c|c|}
\hline & sd & 5.21 & 3.65 & 2.73 & 2.33 & & 2.48 \\
\hline & $\min$ & 2.01 & 0.39 & 0.40 & 0.95 & & 0.73 \\
\hline & $\max$ & 24 & 20.3 & 18.5 & 15.2 & & 14.9 \\
\hline & $n$ & 37 & 47 & 67 & 68 & & 119 \\
\hline \multirow{6}{*}{ Zn } & Geometric mean & 23.5 & 24.6 & 21.4 & 26.3 & & 10.9 \\
\hline & Arithmetic mean & 33.7 & 30.3 & 26.0 & 35.8 & & 15.4 \\
\hline & sd & 31.9 & 26.4 & 16.8 & 42.5 & & 24.7 \\
\hline & $\min$ & 7.5 & 10.6 & 5.4 & 6.5 & & 2.3 \\
\hline & $\max$ & 124 & 143 & 94.9 & 303 & & 257 \\
\hline & $\mathrm{n}$ & 37 & 47 & 67 & 69 & & 119 \\
\hline \multirow{6}{*}{ Cd } & Geometric mean & 0.28 & 0.29 & 0.25 & 0.26 & & 0.09 \\
\hline & Arithmetic mean & 0.42 & 0.34 & 0.30 & 0.32 & & 0.11 \\
\hline & sd & 0.44 & 0.23 & 0.20 & 0.22 & & 0.07 \\
\hline & $\min$ & 0.08 & 0.07 & 0.05 & 0.05 & & 0.02 \\
\hline & $\max$ & 1.61 & 1.26 & 1.19 & 1.28 & & 0.37 \\
\hline & $\mathrm{n}$ & 35 & 47 & 67 & 68 & & 119 \\
\hline \multirow{6}{*}{$\mathrm{Pb}$} & Geometric mean & 29.3 & 31.3 & 21.6 & 14.4 & 5.87 & 3.33 \\
\hline & Arithmetic mean & 36.6 & 36.7 & 24.2 & 16.2 & 6.47 & 3.93 \\
\hline & sd & 25 & 21.8 & 12.5 & 7.4 & 3.0 & 2.5 \\
\hline & $\min$ & 5.2 & 5.5 & 6.3 & 3.0 & 1.9 & 0.9 \\
\hline & $\max$ & 107 & 121 & 72.8 & 39.1 & 15.6 & 14.8 \\
\hline & $\mathrm{n}$ & 37 & 69 & 67 & 71 & 129 & 119 \\
\hline
\end{tabular}

Table 2: Summary of aerosol TM concentrations. Geometric mean, standard deviation (computed from arithmetic mean), minimum and maximum concentrations are given in $\mathrm{ng} \mathrm{m}^{-3}$.Data are presented in groups over the observed time: 1986-87, 1992-93, 1994-95, 1997-98, 2003-05 and 2006-08.

Table 3: Intercorrelation matrix of the 9 TMs (119 observations per variable, data set 2006-08). Crustal and anthropogenic TMs show highest intercorrelation values (r). All intercorrelations are significant, except those for $\mathrm{Zn}$, which are only significant for $\mathrm{Cu}, \mathrm{Pb}$ and $\mathrm{Cd}$, highlighting its anthropogenic character.

\begin{tabular}{cccccccccc}
\hline $\mathbf{r}$ & $\mathbf{A l}$ & $\mathbf{F e}$ & $\mathbf{M n}$ & $\mathbf{C o}$ & $\mathbf{N i}$ & $\mathbf{C u}$ & $\mathbf{P b}$ & $\mathbf{C d}$ & $\mathbf{Z n}$ \\
\hline $\mathbf{A l}$ & 1 & 0.96 & 0.87 & 0.85 & 0.59 & 0.43 & 0.31 & 0.33 & 0.07 \\
$\mathbf{F e}$ & 0.96 & 1 & 0.95 & 0.92 & 0.68 & 0.64 & 0.50 & 0.50 & 0.19 \\
$\mathbf{M n}$ & 0.87 & 0.95 & 1 & 0.92 & 0.70 & 0.71 & 0.57 & 0.59 & 0.16 \\
$\mathbf{C o}$ & 0.85 & 0.92 & 0.92 & 1 & 0.80 & 0.71 & 0.50 & 0.52 & 0.16 \\
$\mathbf{N i}$ & 0.59 & 0.68 & 0.70 & 0.80 & 1 & 0.67 & 0.36 & 0.37 & 0.08 \\
$\mathbf{C u}$ & 0.43 & 0.64 & 0.71 & 0.71 & 0.67 & 1 & 0.72 & 0.66 & 0.37 \\
$\mathbf{P b}$ & 0.31 & 0.50 & 0.57 & 0.50 & 0.36 & 0.72 & 1 & 0.81 & 0.62 \\
$\mathbf{C d}$ & 0.33 & 0.50 & 0.59 & 0.52 & 0.37 & 0.66 & 0.81 & 1 & 0.30 \\
$\mathbf{Z n}$ & 0.07 & 0.19 & 0.16 & 0.16 & 0.08 & 0.37 & 0.62 & 0.30 & 1 \\
\hline
\end{tabular}

